\title{
Lukasz Dubiński*
}

Uniwersytet Szczeciński

\section{UNIJNE UJĘCIE ZASADY ZRÓWNOWAŻONEGO ROZWOJU Z UWZGLEDDNIENIEM ZNACZENIA UDZIAŁU EUROPEJSKIEJ AGENCJI ŚRODOWISKA W JEJ WDRAŻANIU (WYBRANE ZAGADNIENIA)}

\section{Streszczenie}

Celem artykułu jest przedstawienie pozycji prawnej zasady zrównoważonego rozwoju w prawie unijnym. Pod tym kątem poddano analizie teksty podstawowych aktów prawnych Unii Europejskiej. Natomiast, ze względu na unijny trend outsourcingu administracyjnego, polegającego na przekazywaniu zadań związanych z integracją europejską tzw. agencjom, podjęto się także rekonstrukcji znaczenia Europejskiej Agencji Środowiska we wdrażaniu konceptu zrównoważonego rozwoju.

Słowa kluczowe: zrównoważony rozwój, prawo unijne, europejska agencja środowiska

\section{Wprowadzenie}

Idea zrównoważonego rozwoju „,w kontekście ochrony środowiska pojawiła się na poziomie traktatowym, gdy w Traktacie z Maastricht zmieniono art. 2 TWE uznając za zadanie Wspólnoty m.in. dążenie do harmonijnego wzrostu gospodarczego z zapewnieniem ochrony środowiska" (Jendrośka, 2013). Natomiast sam koncept

\footnotetext{
"Adres e-mail: lukasz.dubinski@wpiaus.pl.
} 
zrównoważonego rozwoju stanowi pokłosie tzw. raportu Brundtland (Richardson, 1997, s. 47), gdzie zrównoważony rozwój został zdefiniowany jako „rozwój, który zaspokaja potrzeby obecne, nie pozbawiając przyszłych pokoleń możliwości zaspokojenia ich potrzeb" (Płachciak, 2011, s. 243)1.

Celem artykułu nie jest rekonstruowanie prawnego rozumienia samego pojęcia zrównoważonego rozwoju, ponieważ przy aktualnej wielości opracowań dotyczących tego tematu jego przedstawienie musiałoby się sprowadzać do relacjonowania i komentowania powszechnie znanych tez. Zamiast tego, w pierwszej kolejności podjęto się określenia aktualnego (polizbońskiego) znaczenia zrównoważonego rozwoju jako instytucji prawnej dla integracji europejskiej.

Następnie zwrócono uwagę na to, w jaki sposób aktualnie determinowane jest prawne rozumienie pojęcia zrównoważonego rozwoju i związanej z nim ochrony środowiska w kontekście przeobrażania się administracji europejskiej polegającego na coraz szerszym przekazywaniu zadań integracyjnych tzw. agencjom. W związku z tym analizie poddano wpływ na wdrażanie zasady zrównoważonego rozwoju oraz związanej z nim ochrony środowiska agencji właściwej w tych sprawach, czyli Europejskiej Agencji Środowiska.

\section{Zasada zrównoważonego rozwoju w ujęciu traktatowym}

Zasada zrównoważonego rozwoju stanowi jedno z zagadnień otwierających postanowienia Traktatu o Unii Europejskiej (dalej: TUE), co można rozumieć jako uznanie jej za jedną z kluczowych zasad integracji europejskiej. Z preambuły omawianego aktu można również odczytać informację, iż na zasadę zrównoważonego rozwoju należy patrzeć nie tylko z perspektywy ochrony środowiska, ale i zasady spójności oraz postulatu urzeczywistniania rynku wewnętrznego. Na tej podstawie można w pewnym uproszczeniu stwierdzić, iż integracja gospodarek państw członkowskich, czyli tradycyjna domena Unii Europejskiej, powinna przebiegać zgodnie z wytycznymi zasady zrównoważonego rozwoju. Ponadto, zestawienie z tą zasadą oraz ze sobą nawzajem ochrony środowiska, zasady spójności oraz rynku

${ }^{1} \mathrm{~W}$ raporcie Bruntland przywołany cytat przedstawiono w rozdziale drugim pod tytułem „W kierunku zrównoważonego rozwoju” (tłum. Ł.D.). Wskazać jednak należy, iż do przywołanego cytatu, jak i do samego raportu dotarłem dzięki wskazanemu w tekście artykułowi Adama Płachciaka, ww. cytat pochodzi również z tej publikacji. 
wewnętrznego należy odczytywać nie tylko jako postulat dotyczący sposobu prowadzenia polityki w każdej tych sfer, ale także jako zobowiązanie do uwzględnienia wzajemnych wymogów (Sjåfjell, Wiesbrock, 2016, s. 8).

W związku z powyższym warto zauważyć, iż wymienione pola oddziaływania zasady zrównoważonego rozwoju zostały de facto powtórzone w treści art. 3 ust. 2 TUE. O ile jednak ww. ujęcie w preambule zasady zrównoważonego rozwoju może zostać uznane wyłącznie za postulowany kierunek prowadzenia polityki administracyjnej czy ewentualnie za pewną wytyczną interpretacyjną dotyczącą przepisów omawianego aktu, to już powtórzenie jej w przywołanym przepisie szczególnym oznacza, iż zasada zrównoważonego rozwoju jest nie tylko postulatem, ale zawiera także wiążącą organy unijne warstwę normatywną (Kerschner, Wagner, s. 61-62). Co więcej, kolejne przepisy TUE (tj. art. 3 ust. 5 oraz art. 21 ust. 2) nakazują organom unijnym kierowanie się zasadą zrównoważonego rozwoju nie tylko w stosunkach wewnętrznych, ale i promowanie tej zasady w relacjach zewnętrznych (Pallemaerts, 2013, s. 360).

W Traktacie o funkcjonowaniu Unii Europejskiej (dalej TFUE) zamieszczony został z kolei tylko jeden przepis odnoszący się bezpośrednio do zasady zrównoważonego rozwoju, czyli art. 11. Zgodnie z nim, przy ustalaniu i realizacji polityk i działań Unii, w szczególności w celu wspierania zrównoważonego rozwoju, muszą być brane pod uwagę wymogi ochrony środowiska. Z jednej więc strony, w porównaniu z przedstawionymi na wstępie regulacjami, w TFUE jest mowa o zasadzie zrównoważonego rozwoju w znacznie węższym zakresie, jedynie w odniesieniu do relacji wymogów ochrony środowiska z pozostałymi politykami unijnymi. Z drugiej jednak strony, sposób ujęcia w art. 11 TFUE przywołanej relacji determinuje wszelkie aspekty działalności administracji unijnej (Sjåfjell, 2015, s. 45), a więc i integracji europejskiej. Stąd w literaturze jest on określany jako zasada integracji (Cenevska, 2016, s. 139).

Wprowadzenie art. 11 TFUE wynikało m.in. z refleksji, zgodnie z którą z natury rzeczy przepisy nieśrodowiskowe mają inne niż proekologiczne cele (np. służące zwiększaniu konkurencyjności gospodarki europejskiej) i tym samym ich wykonywanie może zagrażać środowisku naturalnemu (Scotford, 2017, s. 87). Można więc przyjąć, iż chodzi o uniknięcie niespójności w unijnym systemie prawnym polegającej w uproszczeniu na tym, iż jednocześnie przyjmowane i wykonywane są tak przepisy szkodzące, jak i chroniące środowisko. Nie wydaje się jednak, żeby 
omawiany przepis można było odczytywać w ten sposób, iż ochrona środowiska stała się (jedynym) celem integracji europejskiej samym w sobie. Uwzględniając bowiem chociażby wcześniejsze uwagi, można stwierdzić, iż chodzi o to, że nieśrodowiskowe polityki Unii Europejskiej powinny przynajmniej nie szkodzić ochronie środowiska. Innymi słowy, realizacja celów polityk nieekologicznych nie może abstrahować od zakładanych w przepisach środowiskowych celów proprzyrodniczych (Nowag, 2015, s. 28, 29).

Podsumowując można powiedzieć, iż zasada zrównoważonego rozwoju pełni w art. 11 TFUE funkcję łącznika między wymogami ochrony środowiska a pozostałymi politykami unijnymi. Natomiast na marginesie podnieść należy, iż analogicznie jak w rozwiązaniach przedstawionych na wstępie, tak i w przypadku TFUE nie można mówić o ustaleniu w prawie traktatowym jednoznacznego sposobu rozumienia ani pojęcia zrównoważonego rozwoju, ani ochrony środowiska.

\section{Zasada zrównoważonego rozwoju w Karcie Praw Podstawowych Unii Europejskiej}

Problematyka zrównoważonego rozwoju została podjęta już w preambule Karty Praw Podstawowych Unii Europejskiej (dalej: Karta), gdzie wskazano, iż dążenie Unii Europejskiej do stałego i zrównoważonego rozwoju zostało ujęte w oderwaniu od konkretnej sfery jej aktywności (np. gospodarki). Należy więc przyjąć, iż interpretacja poszczególnych postanowień Karty nie może co najmniej abstrahować od konceptu zrównoważonego rozwoju, a powinna wręcz stanowić jeden z punktów odniesienia w procesie wykładni poszczególnych postanowień Karty.

W oczywisty sposób umiejscowienie zasady zrównoważonego rozwoju w preambule, której natura wynikająca z techniki legislacyjnej opiera się wyłącznie na postanowieniach bazujących na pojęciach niedookreślonych, wyłącza możliwość wprowadzenia w tej części aktu prawnego definicji legalnej omawianej zasady. Wydaje się więc, iż połączenie w jednym akapicie zrównoważonego rozwoju z informacją o tym, iż jest on celem aktywności Unii Europejskiej, pozwala na przyjęcie, iż będzie tu chodziło o taki sposób rozumienia konceptu zrównoważonego rozwoju, jaki został zaprezentowany w przedstawionych na wstępie traktatach. Można również przyjąć, iż wdrażanie postanowień Karty z tej perspektywy oznacza, że i jej postanowienia stanowią instrument urzeczywistniania zrównoważonego rozwoju przez Unię Europejską oraz państwa członkowskie. 
Z kolei, w ramach rozwiązań szczegółowych Karty, koncept zrównoważonego rozwoju pojawia się wyłącznie w jej art. 37 mówiącym o konieczności zintegrowania wysokiego poziomu ochrony środowiska z politykami Unii Europejskiej i zapewnieniu zgodności właśnie z zasadą zrównoważonego rozwoju. W literaturze trafnie zauważa się, iż konstrukcja przywołanego przepisu ${ }^{2}$ w jednoznaczny sposób uniemożliwia uznania go za podstawę dla indywidualnego prawa do środowiska (Lombardo, 2010, s. 223). Tym niemniej, umieszczenie art. 37 w Karcie stanowi jasny przekaz ze strony prawodawcy, iż należy go oceniać w kontekście praw człowieka (Hedemann-Robinson, 2007, s. 351). Tym samym, wykładnia tego przepisu nie powinna być nakierowana wyłącznie na potrzeby przyrody jako takiej oraz zbiorowości ludzkiej, ale także i jednostki. Można więc powiedzieć, iż brak indywidualnego prawa powinien być rekompensowany w ten sposób, iż to na administrację unijną został nałożony obowiązek uznawania wymogów polityki proekologicznej z uwzględnieniem potrzeb jednostki jako punktu wyjścia dla określania kierunku prowadzenia pozostałych polityk unijnych, a więc przede wszystkim dla determinowania ich podstaw prawnych.

Biorąc z kolei pod uwagę ogólnikowy charakter art. 37 Karty, przyjąć należy, iż jego znaczenie należy rozpatrywać w aspekcie imperatywu pewnego kierunku prowadzenia polityki oraz oceny już dokonanych działań (np. implementacji przepisów unijnych przez państwa członkowskie), a nie jako samoistnej podstawy do określania szczegółowych wymogów ochrony środowiskowej (Fleurke, 2016, s. 390).

\section{Europejska Agencja Środowiska}

Europejska Agencja Środowiska (dalej: agencja środowiskowa) jest zaliczana do grupy tzw. agencji zdecentralizowanych. Chodzi tutaj o nieopisane w europejskim prawie pierwotnym instytucje administracji unijnej. Natomiast rekonstruowanie ich znaczenia oraz zasad funkcjonowania nie jest oparte na wspólnych zasadach, a na podstawie odrębnych aktów prawnych powołujących każdą agencję zdecentralizowaną do istnienia.

${ }^{2}$ Literalna treść art. 37 Karty: „Wysoki poziom ochrony środowiska i poprawa jego jakości muszą być zintegrowane z politykami Unii i zapewnione zgodnie z zasadą zrównoważonego rozwoju'. 
Działalność agencji środowiskowej jest aktualnie prowadzona w oparciu o rozporządzenie Parlamentu Europejskiego i Rady (WE) nr 401/2009 z 23 kwietnia 2009 roku w sprawie Europejskiej Agencji Środowiska oraz Europejskiej Sieci Informacji i Obserwacji Środowiska (dalej: rozporządzenie agencyjne). Jak wynika z art. 1 ust. 2 tego aktu, aktywność agencji środowiskowej ma zapewnić realizację przez Unię Europejską oraz państwa członkowskie celów w zakresie zrównoważonego rozwoju, jak i w zakresie ochrony i poprawy środowiska, które zostały określone w Traktacie i w kolejnych programach działania Wspólnoty w dziedzinie środowiska. Przy tym, zgodnie z treścią przywołanego przepisu, wsparcie dla administracji unijnej oraz administracji państw członkowskich ma opierać się na dostarczaniu informacji oraz pomocy naukowej i technicznej.

Na podstawie powyższego można więc stwierdzić, iż agencja środowiskowa nie posiada indywidualnych celów „dla samej siebie”, a pełni funkcję służebną wobec administracji unijnej oraz administracji państw członkowskich. Ponadto, przywołany sposób realizacji swoich zadań (tj. dostarczanie informacji i udzielanie wsparcia) z natury rzeczy nie powinien przekładać się na konkretne obowiązki podmiotów współpracujących z agencją środowiskową. Potwierdzenie tej tezy można wyczytać pośrednio z treści rozporządzenia środowiskowego. Chodzi o to, iż prawodawca unijny nie przewidział wprost $\mathrm{w}$ postanowieniach rozporządzenia środowiskowego negatywnych konsekwencji postępowania w sposób niezgodny z informacjami przedkładanymi przez agencję środowiskową. Wskazać również należy, iż agencja środowiskowa inaczej niż np. Europejska Agencja Bezpieczeństwa Lotniczego nie została w żadnym aspekcie swojej działalności wyposażona w kompetencje władcze. Prawodawca unijny nie przyznał również omawianej agencji kompetencji do egzekwowania wykonywania jej ustaleń. $Z$ tej perspektywy można było mówić o wyjątkowo słabej pozycji agencji środowiskowej w strukturze administracji unijnej, a co za tym idzie, z potencjalnie faktycznym brakiem znaczenia efektów jej działalności, w tym w odniesieniu do wdrażania zasady zrównoważonego rozwoju.

Na kompetencje agencji środowiskowej można jednak spojrzeć również i z innej strony. Otóż, podstawowym efektem jej działalności jest, zgodnie z ww. art. 1 rozporządzenia agencyjnego, informacja, która może z kolei zgodnie z art. 2 rozporządzenia być przedstawiana w różnych formach (np. sprawozdań) i to zarówno z inicjatywy własnej agencji środowiskowej, jak i na wniosek. Prawodawca unijny nie przewidział przy tym możliwości zaskarżenia informacji przedstawianych przez 
agencję środowiskową. Innymi słowy, ustalenia tej agencji mają walor ostateczności. Idąc dalej, można również powiedzieć, iż tylko ona może je zmienić. Abstrahując nawet od czysto legalistycznego podejścia do wymienionej wyżej „informacji”, należy zauważyć, iż z natury rzeczy jest to przekaz o charakterze czysto faktograficznym, a więc pozbawiony elementów subiektywnych. Tym samym, również i z tego punktu widzenia, podważanie ,informacji” staje się bezprzedmiotowe, ponieważ obrazowo rzecz ujmując - wiązałoby się de facto z ,zaskarżaniem rzeczywistości”.

W związku z powyższym przypomnieć należy, iż ani zrównoważony rozwój, ani szczególnie mocno związana z nim ochrona środowiska nie doczekały się uściślenia w tekstach traktatów. Natomiast, jak wskazano powyżej, prawodawca unijny przyznał agencji środowiskowej swoistą kompetencję do ustalania, jak są zbudowane „fragmenty rzeczywistości” związane z ochroną środowiska oraz zrównoważonym rozwojem. Dane przedstawiane przez agencję środowiskową powinny więc stanowić przynajmniej punkt wyjścia dla organów administracji unijnej odpowiedzialnych za wdrażanie wymogów dotyczących ochrony środowiska, jak i sposobu pojmowania zrównoważonego rozwoju.

Warto również zauważyć, iż mechanizm integracji europejskiej zakłada znaczny udział parlamentów państw członkowskich oraz ich administracji we wdrażaniu rozwiązań unijnych, co stanowi pokłosie zasady pomocniczości (subsydiarności). Należy więc mówić o pewnej swobodzie związanej z przywołaną zasadą. Chodzi tutaj o założenie, zgodnie z którym sposoby rozwiązywania problemów krajowych najlepiej są wdrażane za pomocą lokalnie ustalanych środków. Z drugiej strony, niedopuszczalne jest podejmowanie przez wspomniane podmioty krajowe działań, które uniemożliwiałyby lub przynajmniej znacznie utrudniałyby wypracowanie minimalnego wspólnego europejskiego standardu jako elementu spajającego państwa członkowskie w ramach Unii Europejskiej. Natomiast, skoro oczywistym miernikiem jakości działań jest ich skuteczność, to wypracowywany, minimalny standard europejski powinien zasadzać się na obiektywnych ocenach rzeczywistości. Można więc uznać informacje prezentowane przez agencję środowiskową za punkt odniesienia w tym zakresie i - w konsekwencji - za istotny element spójności integracji europejskiej. 


\section{Podsumowanie}

W świetle postanowień podstawowych aktów prawnych Unii Europejskiej, koncept zrównoważonego rozwoju stanowi jedną z podstawowych reguł prawnych integracji europejskiej. Należy jednak zwrócić uwagę na fakt, iż prawo traktatowe jedynie zarysowuje kontury pewnego modelu i kierunku integracji europejskiej w zakresie zrównoważonego rozwoju, jak i ochrony środowiska, i w tym duchu narzuca reguły postępowania administracji. Natomiast podstawy jej działania odnoszące się zarówno co do diagnozy stanu obecnego (punktu wyjścia dla dalszych działań), jak i przyjmowanego miejsca docelowego, powinny opierać się na rzeczywistej ocenie sytuacji wypływającej z informacji przedkładanych przez agencję środowiskową.

\section{Literatura}

Cenevska, I. (2016). The European Atomic Energy Community in the European Union Context: The 'Outsider' Within. Leiden-Boston: Koninklijke Brill NV.

Fleurke, F. (2016). EU Climate Law and Human Rights: New Prospects for Judicial Environmental Activism? W: P. Delimatsis (red.), Research Handbook on Climate Change and Trade Law (s. 375-393). Cheltenham-Northampton: Edward Elgar Publishing.

Hedemann-Robinson, M. (2007). Enforcement of European Union Environmental Law: Legal Issues and Challenges. Abingdon: Routledge-Cavendish.

Jendrośka, J. (2013). Komentarz do art. 37. W: A. Wróbel (red.), Karta Praw Podstawowych Unii Europejskiej. Komentarz. Warszawa. Pobrano z: https://sip.legalis.pl/document-view.seam?documentId=mjxw62zoge2tambvgiydenboobqxalrsgaztonrtheyq\#srod tyt5.

Karta Praw Podstawowych Unii Europejskiej. Dz. Urz. UE 2012 C 326/391.

Kerschner, F., Wagner, E. (2016). Sustainability - A Long Hard Road. W: V. Mauerhofer (red.), Legal Aspects of Sustainable Development: Horizontal and Sectorial Policy Issues (s. 57-80). Cham, Heidelberg, New York, London, Dordrecht: Springer International Publishing.

Lombardo, M. (2010). The Charter of Fundamental Rights and the environmental policy integration principle. W: G. Di Federico (red.), The EU Charter of Fundamental Rights: From Declaration to Binding Instrument (s. 217-240). Heidelberg, New York, London, Dordrecht: Springer Science+media B.V. 
Nowag, J. (2015). The Sky is the Limit: On Drafting of Article 11 TFEU's Integration Obligation and its Intended Reach. W: B. Sjåfjell, A. Wiesbrock (red.), The Greening of European Business Under EU Law: Taking Article 11 TFEU Seriously (s. 15-30). Abingdon-New York: Routledge.

Pallemaerts, M. (2013). Developing More Sustainably. W: A. Jordan, C. Adelle (red.), Environmental Policy in the EU: Actors, institutions and processes (s. 346-366). Abingdon-New York: Routledge.

Płachciak, A. (2011). Geneza idei rozwoju zrównoważonego. Ekonomia, 5 (17), 231-248.

Richardson, D. (1997). The Politics of Sustainable Development. W: S. Baker, M. Kousis, D.

Richardson, S. Young (red.), Politics of Sustainable Development, Theory, policy and practice within the European Union (s. 43-60). London-New York: Routledge.

Rozporządzenie Parlamentu Europejskiego i Rady (WE) nr 401/2009 z dnia 23 kwietnia 2009 r. w sprawie Europejskiej Agencji Środowiska oraz Europejskiej Sieci Informacji i Obserwacji Środowiska. OJ L 126, 21.5.2009.

Scotford, E. (2017). Environmental Principles and the Evolution of Environmental Law. Oxford-Portland, OR: Hart Publishing.

Sjåfjell, B. (2015). The Role of Business Law in the Jigsaw Puzzle of Sustainability. Building Sustainable Legacies: The New Frontier of Societal Value Co-Creation, 5, 42-56.

Sjåfjell, B., Wiesbrock A. (2016). Why Should Public Procurement Be about Sustainability?

W: B. Sjåfjell, A. Wiesbrock (red.), Sustainable Public Procurement Under EU Law: New Perspectives on the State as Stakeholder (s. 8-22). Cambridge: Cambridge University Press.

Traktat o Funkcjonowaniu Unii Europejskiej. 2016/C 201/01.

Traktat o Unii Europejskiej. 2016/C 201/01.

\title{
CONCEPTUALIZATION OF SUSTAINABLE DEVELOPMENT IN EU LAW WITH REGARD TO THE SIGNIFICANCE OF PARTICIPATION OF THE EUROPEAN ENVIRONMENT AGENCY IN ITS IMPLEMENTATION (SELECTED ISSUES)
}

\begin{abstract}
The aim of the article is to present the legal position of the principle of sustainable development in EU law. Taking this into account, the texts of the basic acts of the European Union were analyzed. On the other hand, due to the EU's trend of administrative
\end{abstract}


outsourcing, which is the transfer of tasks related to European integration to co called agencies, there was also a reconstruction of the significance of the European Environment Agency in implementing the concept of sustainable development.

Keywords: sustainable development, EU law, European Environment Agency

JEL code: K19 